\title{
Archaeologies of Sound: Reconstructing Louis MacNeice's Wartime Radio
}

\section{Publics}

Ian Whittington

[Note: This version represent's the author's original accepted submission, and does not include certain minor changes made prior to publication. For the final version, see Modernist Cultures 10.1 (March 2015): 44-61]

Hailing Louis MacNeice's radio blitz feature Westminster Abbey in her September 1941 review for The Listener, critic Grace Wyndham Goldie notes how the sounds of the broadcast consolidated the scattered anxieties of war. 'There were lines in this programme,' she writes, 'which crystallised, suddenly and with dramatic force, the diffused emotions which most of us feel in face of the defence of London. [...] Planes drive overhead; and when the air is filled with the shriek of falling bombs and the crash of explosions a voice within the damaged Abbey cries "Who is on the watch tonight?"' For Goldie, the cacophony evoked a bodily response: 'In its setting this produced the vision-seeing, spine-shivering stir of the imagination which is as real as fear. It was one of those moments which broadcasting and drama exist to create. 'i With the blitz a recent memory, MacNeice's hallucinatory blend of sirens, fire bells, and bombers confronted British listeners with the aural image of their precarious wartime existence. In so doing, it invited them to participate in a national mythology - already under construction - of vulnerability endured.ii

Goldie's enthusiastic response reminds us that, in the crowded soundscape of Second World War Britain, radio resonated within bodies attuned to danger. Hitler barked on the wireless, news of the conflict poured in from all corners of the globe, and German propagandists including William Joyce (the infamous 'Lord Haw-Haw') invaded the radio 
sets of the nation. For British listeners, the very declaration of war was a sonic event: minutes after Chamberlain announced over the airwaves on 3 September 1939 that Britain and Germany were at war, air raid sirens sounded over London. The timing seemed, as Nancy Mitford noted in her Phoney War novel Pigeon Pie (1940), like ‘some curious practical joke' to those listeners who 'supposed their last moment was at hand.'iii Taking into account other, more positive radio figures like Winston Churchill and J.B. Priestley, and shows like ITMA and The Brains Trust, wartime Britain appears not so much a nation of shopkeepers as a nation of listeners-in. ${ }^{\text {iv }}$ In the miasma of black-outs and bomb shelters, Britons experienced the Second World War as pervasively audible.

Attempts to recover this audible experience of war remain frustrated by the paradox that the acoustic past is available in theory but elusive in practice. Such radio recordings as do exist exert a phenomenological pull qualitatively different from that of print, inviting present-day listeners to participate belatedly in what Jason Loviglio has called the 'intimate public' of radio.v The laudable goal of much recent radio studies to grapple with the recorded artefact itself, rather than its paratextual paper trail, is hindered by the fact that in many cases such recordings are incomplete or non-existent. ${ }^{\text {vi }}$ Of the many tens of thousands of broadcasting hours that took place during the war on the BBC Home Service, Forces Programme (later the Light Programme), and Overseas Service, only a fraction endure in recorded form; the recordings of MacNeice's Westminster Abbey, for example, have not survived. This paucity of acoustic information compounds a greater problem underlying attempts to reconstruct the world of the listener: even with access to recordings, is it possible to understand a historically embedded and embodied act of listening? Vibrations in the air made by a broadcast or a recording exist as physical phenomena, material facts as it were; sounds, on the other hand, exist within particular human cultures and histories.vii 
Because hearing is itself an internal process - no matter how publicly conducted - its variations will be manifold. Even the thickest description of a particular historical moment risks reducing a diversity of embodied listening experiences into a single one.

The plurality of solipsistic listening experiences, and their relatively scattered and thin representation in historical accounts, means that radio scholarship must approach past audition obliquely, as an essentially irrecoverable experience knowable only by its external material traces. viii As Jonathan Sterne notes, the fact that we might not recover the fleeting experience of listening as it happened should not stop us from 'interrogating the conditions under which that experience became possible in the first place,' reconstructing lost audition as an event enmeshed in larger social and historical contexts. ${ }^{\text {ix }}$ Scholars outside of radio studies, for instance, have sought to capture similarly transient sensory experiences by reconstructing entire environments of sound and smell from historical evidence. ${ }^{x}$ Such projects offer useful models for archival reconstruction, but must be approached with some caution. Attempts to recover an idealized past listening experience risk participating in what Dominick LaCapra has called a fetishization of the archive, in which the archive is no longer simply 'the repository of traces of the past which may be used in its inferential reconstruction' but becomes 'a stand-in for the past that brings the mystified experience of the thing itself.'xi Archival reconstructions must always position themselves as contingent and partial achievements; their conclusions are not so much absolute certainties as productive interpretations.

\section{National Space and the Radio Public}

One means of reconstituting the social and political contexts of past listening is to begin from the seemingly elementary premise that radio listening was always experienced 
both spatially and temporally. Radio often invites analysis that emphasizes the temporal, from narrative-based studies of radio drama that focus on the unfolding of plot and the progressive development of character, to institutional histories and single-author studies that place a given broadcast in the broad arc of authorial or corporate development. But recent work by scholars including Loviglio and Neil Verma has reasserted radio's status as a medium of spatiality: not only do the environments of its production and consumption affect the broadcast, but the broadcast itself works to conjure acoustic environments of its own. In an American context, Verma has shown how the radio drama of the 1930 and 1940 demonstrates a reflexive concern with forging these imagined spatio-temporal realities and cueing audiences to navigate within them; this concern, Verma argues, was related to the widespread conceptualization of radio as a medium that annihilated distance.xii Put another way, the acoustic spaces of radio drama bear traces of the circumstances and anxieties behind their own construction; they enact a rhetoric of listening specifically geared to their imagined audience. Linking dispersed environments of sonic production and reception, radio drama provided a medium for the contemplation of relations of distance, constructing elaborate heard environments while simultaneously teaching listeners to orient themselves within it. ${ }^{x i i}$

The notion that radio drama models techniques of listening depends upon its doubled status as reflective and constitutive of a radio public. As Michael Warner has argued, publics are discursive entities that come into existence by virtue of being addressed: 'A public might be real and efficacious, but its reality lies in just this reflexivity by which an addressable object is conjured into being in order to enable the very discourse that gives it existence.'xiv The mode and manner in which broadcasters address their listeners, for example, shapes the listening public by implying qualities and objectives that listeners may 
subscribe to or disagree with; as Warner puts it, 'each decision of form, style, and procedure carries hazards and costs in the kind of public it can define.'xv In times of crisis, furthermore, the publics conjured by radio can have sharply political valences. Loviglio has argued persuasively that Franklin Roosevelt's 'Fireside Chats' of the 1930 s and 1940 s were implicit invitations for listeners to participate in the President's mobilization of public opinion. In a manner typical of the era, his broadcasts pushed at the boundary between public and private by reaching into the domestic sphere of audition in order to draw listeners out into a broader sphere of action.xvi

In wartime Britain, Roosevelt's appeals find their corollary in Winston Churchill's sweeping 'finest hour' rhetoric and J.B. Priestley's demotic invocation of the 'People's War.' But these orations are only the most overt blurrings of the private/public dichotomy; in a state of total war, much, if not all, of the broadcasts of a semi-official agency like the BBC worked to guide listeners' involvement in the nation. xvii ‘Sound made for community of sensation, was emotive' writes Elizabeth Bowen in a 1969 essay on the war years; '[p]ress and radio combined in keeping the people's collective image constantly in front of the people's eyes... It was inspirational; one beheld oneself as one had it in one to be.'xviii Geared towards national mobilization, the imagined spaces of British broadcasting were vehicles for thinking through the problem of collective participation in the war effort.

As one of the most prolific radio writers and producers to emerge at the $\mathrm{BBC}$ during the Second World War, MacNeice serves as an important barometer for such projects of national public-formation. Extensive records document the material production of his broadcasts and their reception as cultural events in the domestic domain of the listener; moreover, MacNeice himself conceived of broadcasting as a medium of imagined spatiality. A devoted student of traditional poetic forms, MacNeice carried a structural mode of 
thought over to broadcasting: 'To found / A castle on the air,' he would recall in Autumn Sequel (1954), 'requires a mint / Of golden intonations and a mound / Of typescript in the trays.'xix The formal demands of a popular acoustic medium replaced those of a poetic one, but were nevertheless able to serve as an outlet for MacNeice’s structural instincts. While radio permitted 'many more liberties with time and place' as compared to stage drama, it nonetheless had to conform to 'a pattern beginning with a careful and intuitive selection of material and culminating in a large architectonic.'xx

This article links the 'large architectonic' of MacNeice's radio dramas with the broader aims of wartime propaganda, reading the spatial orientation of listeners in the radio soundscape as politically charged. In other words, the form of the radio event-its ability to conjure an imagined space through words, music, and effects-is inextricably tied to the historical conditions of production and reception. As an employee of the Features Department, which was responsible for programming of historical, informative, or propagandistic intent, MacNeice's job was to bring listeners in Britain and overseas into alignment with the goals of the British war effort. Moreover, as the war went on, MacNeice's project of listener orientation was increasingly directed towards questions of post-war planning. Two of MacNeice's most important wartime broadcasts, the verse epics Alexander Nevsky (1941) and Christopher Columbus (1942), use aurally astute characters and deep acoustic spaces to model the process of hearing through the crowded soundscape of war. The plays build auditory worlds that mediate between the poles of hearing as a subjective, interior practice and listening as a public activity with political resonances. With Christopher Columbus, however, MacNeice directs this listening beyond a faith in victory, towards a national future bound not by conflict but by a common goal of material and social reconstruction. When read in concert with accounts of listener attitudes and practices, 
MacNeice's acoustic parables betray the concerns of those broadcasters who sought to bridge individual and collective functions of audition, and to translate intimate hearing into public listening.

\section{Towards an Audile Technique: Alexander Nevsky and the Wartime}

\section{Soundscape}

Upon his return from an extended sojourn in America in December of 1940, MacNeice joined the BBC Features Department, where he learned to adapt his interest in traditional poetic structures to the formal demands of radio under the direction of Lawrence Gilliam. 'Features,' as the department was known, offered MacNeice a crash-course in the practice of propaganda. Among MacNeice's important early work was a series of short features aimed at American listeners, The Stones Cry Out, in which the history of buildings damaged by German bombing raids was brought to life through a blend of documentarystyle sound effects, overlapping narrative voices, and historical re-enactments. ${ }^{\mathrm{xxi}}$ Through these short vignettes, MacNeice sharpened his skills at evoking both the particularities of the wartime environment and the broader socio-historical arc into which the present conflict fit. In an internal memo of 21 July 1941, Gilliam praised his work, calling it 'radio art of a high order' and claiming that 'MacNeice is absolutely indispensable to our war-time feature output.'xxii

This early work in the Features Department taught MacNeice that broadcasting had to attend to the social circumstances of listening, which included the constraints of war and the varied tastes of an audience spread across Britain and around the English-speaking world. In the introduction to the published version of Christopher Columbus (1944), he notes that radio drama is 'a popular art form which is still an art form,' even if its audiences 
must 'be reckoned in millions.' xxiii MacNeice describes the radio public as 'unconscious that it is an audience' and claims that in order to reach them one must 'forget about "literature" and... concentrate upon sound. ${ }^{\text {'xxiv }} \mathrm{A}$ focus on sound returns the radio writer to the originary moment of literature:

[EXT:] This is not to deny literature, for this is how literature began-the Homeric or Icelandic bard shouting over the clamour of the banquet, the "tale told in a chimney corner' while tankards clatter and infants squawl and somebody makes up the fire and old men snore and cough. The radio listener listens in a terribly everyday setting; there is no auditorium to beglamour him and predispose him to accept you; if you want him to accept you, you will have to seduce him by sound and sound alone.xxv

This reliance on sonic seduction, born of the audience's cacophonous environment, required that radio operate on what MacNeice referred to as 'a more or less primitive plane,' appealing to the emotions rather than to the reason of the audience. ${ }^{x x i}$ He would later moderate this stance, claiming that radio must always appeal on the 'primitive' plane of entertainment, though it may seek to do more beyond that. ${ }^{x x v i i}$ MacNeice's emphasis on the socially embedded practice of listening, however, would remain undisturbed. In the posthumously published introduction to his radio plays The Mad Islands and The Administrator, MacNeice acknowledges that some already considered broadcasting 'an obsolescent medium,' and admits that television had 'stolen most of its public though it cannot take over most of its territory.' ${ }^{\text {xxviii }}$ Both during and after the war, MacNeice was aware that radio could only draw listeners into a sense of imagined national community by first cutting through the crowded auditory field.

The Stones Cried Out prepared MacNeice for larger projects that lay ahead, the first 
of which was an adaptation of Sergei Eisenstein's 1938 film Alexander Nevsky in the fall of 1941. xxix The film had obvious propaganda value; created as an anti-Nazi propaganda piece, Eisenstein's Nevsky follows the title character, a $13^{\text {th }}$-century Russian prince, as he assembles a peasant army to defeat an invading horde of Teutonic knights. MacNeice jumped at the chance to work on a grand scale, and began drafting a script that borrowed the syllabic metre and epic characterizations of Anglo-Saxon and Norse poetry. With its pared-down dialogue and striking geometric framing, however, the film posed material challenges for radio adaptation, particularly in the climactic battle sequence between Russian and Teutonic forces on the frozen ice of Lake Peipus. For this extended scene, MacNeice opted to forge a diegetical surrogate for the listener by creating a visually impaired character not present in the original film: Blind Iuri, an elderly man unable to participate in the battle, listens from the sidelines while a young woman named Marya and other characters relate the struggle to him. As an archetypal auditor, Iuri enables the narration of the battle scene in Nevsky and, by extension, the audience's vicarious experience of that battle. Like the radio listener, Iuri submits to and occasions the translation of the world into acoustic experience.

Iuri's blindness moves beyond disability to afford him new kinds of perception, oriented towards the future. When things initially seem to be going badly for the Russians, Iuri claims, against Marya's incredulous protests, that they will ultimately triumph: 'That isn't the way I see it /... I know I'm blind. That is just why / I see the way things go.'xxx Iuri's second sight is compounded by the fact that, as Marya herself admits, 'I can't see more than you can hear.'xxxi Though ostensibly speaking to Iuri, Marya simultaneously reassures the radio listener that to attempt to watch this battle would be superfluous; listening is enough. When a soldier who had just been speaking to Iuri and his daughter returns to the distant 
battlefield where he appears to suffer a fatal blow, the blind man remarks that 'When he was here just now / I heard the death in his voice.'xxxii Iuri's auditory acuity straddles the interpretive and the predictive. He not only hears more, and better, than other characters do; he hears into the future. He functions as a Tiresias figure, deprived of sight but gifted with insight. 'I can see nothing with the outward eye,' as Iuri says early in the play, 'But with the eye of the mind I can see only too much.' ${ }^{\text {xxxiii }}$

MacNeice was not wholly original in using visual impairment to allegorize the listener's position; the playwright's use of a blind character echoes other instances of visual deprivation in radio drama. The first play written for radio in Britain, A Comedy of Danger (1924), is set in a darkened coal mine; Dylan Thomas's Under Milk Wood (1954) features narration by the blind Captain Cat; and MacNeice's own The Dark Tower (1946) includes a visually impaired prophet named Blind Peter. ${ }^{x x x i v}$ But MacNeice's choice of Blind Iuri as entry point to the battle in Alexander Nevsky goes beyond such representations of the "blindness" of the medium of radio; Iuri channels the specific message that listening is a skill to be learned and honed as a means of participation in the war. Other characters reinforce this lesson for the audience: when a soldier complains that he cannot see the progress of the battle because of the sweat in his eyes, Nevsky advises, 'Then perhaps you can hear ... / That is the ice ahead; the lake is breaking up. / Halt your men and leave the Germans to it. 'xxxv Nevsky's superior hearing warns him that the failing lake ice will soon swallow the remaining German soldiers, weighted down with iron armour. Just as close listening can attune listeners to the sounds of victory, failure to listen closely carries dangers for both characters and, by extension, the radio audience. Early in the play, the 'Grand Master,' leader of the Teutonic forces, threatens both the Russian peasantry and British listeners with despotic oratory: 'A deaf people that will not listen to reason / Must listen to 
fire and sword.'xxxvi

These multiple imperatives assert that passive listening is insufficient; rather, listeners must actively remain open to sonic details if they wish to extract meaning, whether of victory or death, from a work of acoustic art. MacNeice's emphasis on the skill of listening in Nevsky implies a veneration of what Jonathan Sterne calls 'audile technique.' As soundreproduction technologies proliferated over the course of the $19^{\text {th }}$ and early $20^{\text {th }}$ century, audile technique became the mark of specialist listeners, those possessed of discerning ears. It was initially mobilized in professional situations - medical examination by stethoscope, or the transcription of wireless telegraphy, for example - but became a broader social practice with the popularization of technologies like the phonograph and the radio. ${ }^{\mathrm{xx} x \mathrm{ii}}$ Through the privatization and commodification of acoustic space - the appearance of radios in private homes and the development of individual listening practices - listeners acquire audile technique as a form of techno-cultural currency, a savoir-écouter that can then be translated into collective listening practices. ${ }^{\text {xxxvii }}$

In Alexander Nevsky, audile technique, represented as a marker of prophetic skill on the battlefield, incites the listener to astute aesthetic participation as a form of Home Front participation. It seems this emphasis on listening over seeing worked for many listeners. Post-transmission reports indicate that Alexander Nevsky was hailed as a great success upon broadcast. 'Here in fact is radio conquered at last and used at last for living purposes by a living poet,' wrote Grace Wyndham Goldie in the pages of The Listener. ${ }^{\text {xxxix }}$ Goldie waxed enthusiastic about the translation from screen to speaker:

[EXT:] Here we have Louis MacNeice taking a Russian film and turning it into magnificent radio; here we have the physical excitement which sight gives in the cinema translated into the physical excitement of the rhythm of spoken 
verse; here we have the sweep of a cavalry charge put over the air ...until the beat of the words turned into the beat of the hoofs of horses galloping over frozen ground..$^{x l}$

Even listeners not on the BBC payroll agreed; according to the BBC Listener Research Report for the play, $15.2 \%$ of the adult public of the UK tuned in to hear Nevsky, and the play earned a very high 'Appreciation Index’ of 83\%. One listener cited in the report, identified only as 'Housewife,' called the play ‘A great triumph for Louis MacNeice... Personally I didn't keep calm enough to be highly critical, which is the greatest test of its perfection. 'xli In large part, MacNeice's use of Blind Iuri to justify the narration of the battle seems to have eased the transition from screen to radio. A Listener Research report produced following the rebroadcast of Nevsky in April of 1942 noted that ' $[\mathrm{s}]$ everal listeners said they thought the description of the battle on the ice by the blind singer was the outstanding feature of the broadcast, praising it particularly for its realism and dramatic qualities.'xlii The comment is telling; while Iuri does not describe the battle, he does enable the description. The slippage between Iuri as auditor and narrator described in this listener report implies that listening may not be so passive after all, and that the radio public has a role to play in the interpretation of battles both fictional and actual.

Transmitted at 9:20 in the evening on the $8^{\text {th }}$ of December, 1941, Alexander Nevsky was the culmination of a heady evening of broadcasting. The Japanese Air Force had bombed Pearl Harbor on the morning of December $7^{\text {th }}$, bringing the United States into the war. As a result, listeners the next day heard statements on the nine o'clock news by both Roosevelt and Churchill confirming the expansion of the Allied forces, followed by a previously scheduled introduction to Nevsky by Soviet Ambassador Ivan Maisky. political impact of MacNeice's lesson in close listening was thus driven home by the 
appearance, at the microphone, of three voices representing the nations who would unite against Nazi Germany. Given the success of MacNeice's pro-Soviet propaganda epic that night, $\mathrm{BBC}$ producers wasted little time in planning a similar welcome for their newest ally, beginning work on Christopher Columbus in early 1942 to celebrate both the $450^{\text {th }}$ anniversary of Columbus's arrival in the Americas and the emergence of America as a combatant in the Second World War. This new play would extend Alexander Nevsky's lessons in close listening: while Nevsky succeeds at instilling in listeners a sense of the importance of audile technique, Columbus directs this technique towards the goals of postwar social reconstruction.

\section{'On, Sail On!': Christopher Columbus}

As a material endeavour, MacNeice's Columbus exceeds Nevsky by almost every measure. Over two hours long, the play features a score by William Walton and production by veteran Dallas Bower, as well as performances by Laurence Olivier, Robert Speaight, and Margaret Rawlings. In all, it took over forty actors, a symphony, two choruses, and a small army of technicians to produce the play. MacNeice's initial outline for Christopher Columbus indicates that the play was, from the outset, a collaborative endeavour. Sent to Bower in January of 1942, MacNeice's detailed, six-page synopsis of Columbus included scene breakdowns and notes on characters. He envisioned an epic production, two hours long, in which score and script work together to produce meaning: 'Music throughout will be used, not only for the purpose of linking sequences, but to reinforce and illuminate the dominant themes. ${ }^{\text {xliv }}$ As per MacNeice's plan, the play comprises two sections: the first hour documents Columbus's protracted attempts to secure funding and support for his projected voyage across the Atlantic. In addition to the obstruction Columbus encounters 
from more conservative members of the church and nobility, his plan is frustrated by the Spanish focus on the liberation of Granada from Moorish control.xlv The second hour concerns the assembly of a crew, the doubt-ridden voyage itself, the arrival in the Caribbean, and Columbus's triumphant return to the Spanish court at Barcelona. Throughout the play, twin Choruses of Doubt and Faith highlight Columbus's inner struggles as he seeks to convince his patrons, his crew, and himself of the validity of his voyage.

Walton's musical passages, developed from MacNeice's guidelines, are crucial to the sonic orientation of the listener. The score provides valuable spatial and social cues; early in the feature, for example, three middle-aged men discuss the recent arrival of Columbus in Lisbon. Referring to the explorer's talk of 'land in the West,' one of the men, Alfredo, exclaims, 'You'd have thought / you were listening to a drunken sailor; / That's the kind of talk you hear in the taverns on the quay,' at which point a gently plucked guitar rises up from the background to lead listeners to the tavern (8). Following an exchange among sailors about such rumoured lands as 'Antilia and Zipangu... / Aye, and Vineland and Hy Brasil' (9), the guitar stops and the voices of the sailors fade out, repeating the names of places that were to them only fables, but which today resonate with their modern cognates and equivalents (the Antilles, Japan, Newfoundland and Brazil). The listener is brought back to the earlier Lisbon room with its three men as Alfredo echoes his own line: 'The kind of talk you hear from drunken sailors!' (9).

This form of listener guidance through the repetition of phrases and musical motifs serves as a kind of echolocation throughout Columbus. The audience, deprived of visual referents, relies on auditory cues to signal scene changes and establish the spatial and sonic environment of each setting. In the example cited above, the guitar music serves to identify 
the tavern as a place of leisure and entertainment, while the near-repetition of Alfredo's phrase about 'drunken sailors' brackets the tavern scene as a kind of temporary spatial cut; it is not a 'flashback' so much as a flash elsewhere. Columbus similarly incorporates plainsong to mark off the scenes taking place at the monastery at La Rabida and 'tribal' drumming in the scenes of contact between indigenous Americans and Columbus. Unlike the repeated demand throughout Nevsky that listeners should develop audile technique as a means of orienting themselves in the wartime soundscape, Columbus presupposes such technique as a prerequisite to an appreciation of the play.

MacNeice and Walton's most effective use of music to generate a sense of spatial and social location occurs as the vessels are being prepared for departure. As the Prior approaches the ships to bless them, the crowd begins to chant the Litany of the Saints (45). Columbus gives the order to weigh anchor, and as the ship pulls away, the litany recedes into the background without disappearing entirely, while the sailors begin to sing an ersatz Iberian shanty:

[EXT:] SoLO: We're bound upon a wild goose chase-

Chorus: pero yo ya no soy yo

SoLO: To find an empire in the West-

Chorus: ni mi casa es ya mi casa. (45)

After several verses, the audience's attention is shifted back to shore by the return of the litany to the sonic foreground and the corresponding fading-down of the shanty. Columbus's lover Béatriz has arrived to see off the ships, and predicts that they will never return, 'Not in a year of palsied months, / Not in an age of haunted years... And all they can do is sing!' (47). At this point, the sound of the sailors, having faded completely from earshot, returns with a new melody joyously out of step with the fatalism of Béatriz's 
prediction and of their own lyrics:

[EXT:]SoLo: Out upon the ocean we're flotsam and jetsam,

Chorus: Gone away for ever, for ever and a day,

SoLo: We're ragtag and bobtail, we're lost and we're lonely,

CHORus: Gone away for ever, for ever and a day. (47)

The fluid movement between musical registers - land and sea, sacred and secular, refined and coarse, establishment and underclass - at once clearly establishes the social and spiritual conditions of each setting, and emphasizes their mutual implication in a common endeavour. Her audition split between a stable world on land and a much less certain, but much more exciting world at sea, the listener hovers in a privileged space of aural surveillance, with the advantage of hearing more than any one character in the feature. This privileged listening position offers an auditory correlative to what Patrick Deer, in his discussion of $20^{\text {th }}$-century wartime cultural production, has called 'oversight,' the ‘commanding perspective' of events offered by official sources of war culture.xlvi As against the totalizing view afforded by maps, aerial photography, and pronouncements of war aims, however, the privileged auditory position in Columbus is immersive and limited; we hear more than any one character, but we do not hear all.

Indeed, the lesson of Christopher Columbus is that while skills of close listening are vital to making sense of events, whether dramatic or historical, those skills must be guided in order to yield the desired political effect. In scripting Columbus's return to Spain, MacNeice indulges in a final, anachronistic gesture of directed listening. Our first exposure to the returned explorer is through the voice of the 'Onlooker,' a narrator-surrogate whose style of speech mimics that of a radio or newsreel commentator:

[EXT:] ONLOOKER: Here they come now, here they come now [...] 
Have a good look, ladies and gentlemen, never again

Will this city of Seville see such a wild to-do.

Look at the shining soldiers bearing coffers of gold,

Look at the tattered banners bleached with the brine,

Look at the red savages crowned with feathers [...] (62)

The Onlooker's repeated injunctions to 'Look' encourage the listener to conjure a mental image of triumphant return, while the rapid-fire delivery mimics familiar forms from the wartime media ecology. The intrusion of twentieth-century media into the world of the play invites the listener to read the events of the play as analogous to events in the world beyond the broadcast, lending a parabolic intensity to the broadcast. Columbus's journey and return are paradoxically made immediate through this anachronistic mediation; the voyage circulates in the very register of contemporaneity - 'news' - through which the wartime radio public most often constituted itself as a community of listeners.

The parable of Columbus's voyage takes on a clearer political valence when read alongside the promotional materials produced to guide listener engagement with the play. The script lacks the most overt indicators of political propaganda: it does not translate Columbus's $15^{\text {th }}$-century enemies into representations of Axis figures, nor does MacNeice insert allegorical markers that offer a clear transposition of events from Columbus's life to the wartime experience of Britons. Instead, Columbus himself offers a model of dedication on which Britain might base its own process of national defence and planning for the postwar world. A notice in The Listener of 8 October 1942 , titled 'On, Sail On!,' lays out this subtext:

[EXT:] Columbus had faith - faith when he was pleading before the grandees, faith when he succeeded eventually in persuading the Spanish queen to grant 
him a ship, faith when he set out with his gaol-bird crews, faith when he faced their incipient mutiny. All the way through, his faith never faltered, and in the end it triumphed. [...] It is in some quarters the fashion to deride those who think and plan ahead: and certain it is that until victory has been won all our plans for a better world will remain but aspirations. But to know, even in the most general terms, the kind of world we are fighting for, is the first step towards that feeling of determination which is necessary to achieve it. And determination is the right arm of faith. xlvii

In this view, Columbus is a model of visionary foresight, an individual capable of seeing beyond the immediate challenge to the promise of riches and new life in undiscovered new worlds beyond. Though in 1940 the topic of post-war planning was sufficiently controversial to occasion J.B. Priestley's notorious exit, pursued by a Tory huff, from the Postscripts series, by 1942 the BBC felt itself independent enough of official government reticence about the post-war future to venture a statement in defence of planning.xlvii Furthermore, the generally progressive tone of The Listener's call for a clear vision of 'the kind of world we are fighting for' implies that currents of social change given fuller voice by the Beveridge Report in December of 1942 were already in popular circulation. ${ }^{\text {xlix }}$

MacNeice had noted this atmosphere as early as the spring of 1941 in his periodic 'London Letters' to Common Sense, a leftist American monthly. Priestley's Postscripts had driven the question of post-war planning to the fore in the summer and fall of 1940, and even with Priestley off the air, questions remained about the British government's commitment to social change following the war:

[EXT:]It has dawned on some people [...] that a clearer consciousness of aims and ends will promote the solution of some practical problems which have been 
falsely divorced from ideology. [...] A clear statement of intended social changes - if they were the right changes (i.e. in the direction of an intelligently planned economy and the levelling out of the social castes) - would enhance the national war effort and heighten, high though it is, the popular morale. ${ }^{1}$

Columbus's vision of perseverance guided by a desire for a new and better world builds on a larger cultural conversation to which the writer was already attuned. The 'New World' of Columbus is not just the land of plenty and promise opened up to Europeans in 1492, nor is it only a metaphor for the new opportunities and optimism made possible by the entry of the US into the war. MacNeice's new world represents the promise of a better collective life realized through shared endeavour.

This notion of a new world made possible through long struggle is echoed, in subtle ways, throughout the broadcast. For example, though Queen Isabella is willing to underwrite the journey to America, she insists that it cannot take place until Spanish forces have defeated the Moors at Granada. When this moment comes, the Chorus greets the event with chants that echo the promise of a new England post-war:

[EXT:] CHORus: The Old Age was iron; the New Age is golden;

The Gold Age is coming-oh see where it comes!

Granada has fallen. The long days of torment

And bloodshed are over; the battle is done

And we are the victors. Granada has fallen

And Spain's resurrection today has begun. ${ }^{\mathrm{i}}$

Guided by paratextual material including the Listener editorial and a similar promotional essay in the Radio Times, listeners were encouraged to hear deeper implications in the choral celebrations of the court at Barcelona; like the Spanish kingdom, Britain was bound 
for a 'resurrection,' however postponed it may be by immediate military imperatives. ${ }^{\text {lii }}$ That Spain itself was, in 1942, under fascist rule lent further significance to this passage. For the British listener in 1942, Granada was at once the city liberated from the Moors in 1491, a city currently under fascist control, and a promise of a more general liberation from war in the unwritten future.

Like Alexander Nevsky, Christopher Columbus was rated highly by listeners, earning an 'Appreciation Index' of 82 and attracting just under $13 \%$ of the available audience. There are signs, however, that the dense soundscape of Christopher Columbus proved challenging to navigate for some listeners. Some thought the subject 'too immense' for a radio play; one unidentified listener quoted in the Listener Research report for Columbus thought the play 'took too much time and concentration for a weekday evening,' while another complained that '[s]ome important information was conveyed in choral singing - a mistake, as the words are seldom audible. 'liii While Listener Research received few such complaints about Columbus, these remarks preserved in the BBC Written Archive Centre reminds us that concentration, audibility, and comprehension are among the many facets of listener experience that vary greatly among members of the radio public. These granular details are prone to escape even the finest of textual nets; while the $\mathrm{BBC}$ archives preserve ample evidence of enthusiasm for both productions from inside the BBC, there are only a few sources of information about audience reactions, and no record of the impact these propaganda broadcasts had on listener attitudes about the war. The choral section touting the resurrection of Spain might be easily interpreted on the page (or with repeated listening) as part of a broader initiative in favour of post-war planning, but its historical effects remain difficult to quantify.

However, by combining close readings of the imagined environments of radio drama 
with paratextual information about the intentions of cultural producers and the reception of cultural products by the audience, we can begin to triangulate the absent experience of listening. As part of a larger BBC initiative to represent the nation to itself, MacNeice's broadcasts simultaneously called into being a listening public and depended on that imagined radio public for its operation; the public served, in Warner's terms, as a 'virtual social object, enabling a special mode of address. 'liv The best of MacNeice's radio broadcasts succeeded, through their navigations of imagined soundscapes, at both conjuring and identifying the nation's experience of the war thus far. To return to the review with which this article opened, Westminster Abbey impressed critic Grace Wyndham Goldie because it simultaneously 'created' an atmosphere of excitement and danger, and 'crystallised' preexisting anxieties which were rapidly being assimilated into a collective narrative about the blitz experience.

Like Westminster Abbey, MacNeice's acoustic explorations of spatial relations in Alexander Nevsky and Christopher Columbus were simultaneously directed inward, to the creation of imaginary sonic environments within the private experience of listening, and outward, suturing the listener into larger socio-political narratives. In the case of wartime Britain, these narratives first of all involved creating a nation of attentive listeners (as manifested in Alexander Nevsky) before directing that listening towards a particular national future. In an abstracted and aestheticized process of national self-formation, MacNeice's radio dramas urged British listeners to participate in the war effort through audile techniques that could reshape their involvement in the war by making them more perceptive citizens. While we cannot reconstruct the experiences of individual listeners, we can trace the outlines of the wartime British radio public as an entity brought into being by the broadcasts they helped to shape. 
i Grace Wyndham Goldie, 'Critic on the Hearth: Radio Drama: The War, MacNeice, and Such,' The Listener Vol. XXVI No. 662 (18 September 1941), p.416.

ii On the real-time mythologization of the blitz, see Angus Calder, The Myth of the Blitz (London: Pimlico, 1993).

iii Nancy Mitford, Pigeon Pie (New York: Popular Library, 1976), p. 10.

iv The phrase 'nation of shopkeepers,' though often attributed to Napoleon, was coined by Adam Smith. See his An Inquiry into the Nature and Causes of the Wealth of Nations (New York: Oxford, 2008), Book IV, Section vii, p. 358.

v Jason Loviglio, Radio's Intimate Public (Minneapolis: University of Minnesota Press, 2005), pp. xii-xxix.

vi See Loviglio; Neil Verma, Theater of the Mind (Chicago: University of Chicago Press, 2012); Christina Baade, Victory Through Harmony (New York: Oxford University Press, 2011); and Debra Rae Cohen and Michael Coyle (eds.), Broadcasting Modernism (St. Petersburg, FL: University Press of Florida, 2009).

vii Jonathan Sterne, The Audible Past (Durham, NC: Duke University Press, 2003), pp. 1012.

viii Elena Razlogova's The Listener's Voice: Early Radio and the American Public (Philadelphia: University of Pennsylvania Press, 2011) is a successful example of the reconstruction of audience attitudes to, and involvement in, radio broadcasting. ix Sterne, Audible Past, p. 28.

x See, for example, Alain Corbin, Village Bells, Sound and Meaning in the Nineteenth Century French Countryside (New York: Columbia University Press, 1998) and The Foul and the Fragrant: Odor and the French Social Imagination (Cambridge, MA: Harvard University Press, 1986); Bruce Smith, 'Tuning into London C. 1600', in Michael Bull and Les Back (eds), The Auditory Culture Reader (New York: Berg Publishers, 2003), pp. 127-136. xi Dominick LaCapra, History and Criticism (Ithaca: Cornell University Press, 1985), p. 92, n.17. xii Verma, Theater of the Mind, p. 25. See also Loviglio, Radio's Intimate Public, pp. xviiixix.

xiii Verma, Theater of the Mind, pp. 19-31.

xiv Michael Warner, Publics and Counterpublics (New York: Zone Books, 2002), p. 67. xv Ibid., p. 14.

xvi Loviglio, Radio's Intimate Public, p. 5. On the tension between public and private modes of audition in the American context more generally, see Radio's Intimate Public, pp. xiv-xix. xvii On the role of the BBC in mediating public participation in, and perceptions of, the war effort, see Siân Nicholas, The Echo of War: Home Front Propaganda and the Wartime BBC, 1939-1945 (Manchester: Manchester University Press, 1996), pp. 1-9 and passim; see also David Cardiff and Paddy Scannell, 'Radio in World War II' (1981), in Andrew Crisell (ed.), Radio (New York: Routledge, 2009), Vol. 2 pp. 170-204.

xviii Elizabeth Bowen, 'The People's War by Angus Calder' (review) (1969), in Hermione Lee (ed.) The Mulberry Tree: Writings of Elizabeth Bowen (New York: Harcourt Brace Jovanovich, 1986), p. 184.

xix Louis MacNeice, 'Autumn Sequel', Collected Poems (New York: Faber, 2007), IV.4-7. xx Ibid, pp. 397, 396.

xxi For details on MacNeice's involvement with The Stones Cry Out and other programs, see Barbara Coulton, Louis MacNeice in the BBC (London: Faber, 1980). Westminster Abbey was in fact an adaptation and extension, for the Home Service, of an earlier episode of The 
Stones Cry Out.

xxii Louis MacNeice, Letters, ed. Jonathan Allison (London: Faber, 2009), p. 445, n. 1. xxiii Louis MacNeice, 'Introduction: Some Comments on Radio Drama', in Alan Heuser and Peter McDonald (eds), Selected Plays of Louis MacNeice (New York: Oxford University Press, 1992), p. 393-4.

xxiv MacNeice, 'Some Comments,' p. 395.

xxv Ibid.

xxvi Ibid.

xxvii Louis MacNeice, 'Author's General Introduction to The Dark Tower and Other Radio Scripts' (1947), in Alan Heuser and Peter McDonald (eds), Selected Plays of Louis

MacNeice (New York: Oxford UP, 1992), p. 403.

xxviii Louis MacNeice, 'Introduction', The Mad Islands and the Administrator (London:

Faber, 1964), p. 7.

xxix Access to recordings of MacNeice's radio plays, including Alexander Nevsky, is currently limited to on-site listening at the National Sound Archive (NSA) at the British Library.

While listening to the original recording of Christopher Columbus is restricted, a recording of the relatively faithful 1992 re-staging on BBC Radio 3 has been known to circulate on internet torrent sites.

xxx Louis MacNeice, Alexander Nevsky, p. 27. Prod. Dallas Bower, Perf. Robert Donat et al. Original transmission 9 December 1941, BBC Home Service. BBC Written Archives Centre, Caversham, UK (hereafter 'BBC WAC').

xxxi Ibid.

xxxii Ibid., p. 30.

xxxiii Ibid., p. 8.

xxxiv In a sadly ironic variation on this theme, MacNeice contracted the pneumonia that would kill him while recording cave effects in Wales for his play Persons from Porlock (1963), which ends with an artist's retreat underground.

xxxv Ibid., p. 36.

xxxvi Ibid., p. 13 .

xxxvii Sterne, The Audible Past, p. 137 and passim.

xxxviii Ibid., p. 159-167.

xxxix Grace Wyndham Goldie, 'Broadcast Drama: The Rise of the Feature,' The Listener 675 (18 December 1941), p. 832.

xl Ibid.

xli BBC Listener Research Section, 'Listener Research Report 493: Alexander Nevsky' (LR/493), 23 December 1941. BBC WAC.

xlii BBC Listener Research Section, 'Listener Research Report 882: Alexander Nevsky' (LR/882), 14 May 1942. BBC WAC.

xliii Christopher Holme, 'The Radio Drama of Louis MacNeice,' in John Drakakis (ed.), British Radio Drama (New York: Cambridge UP, 1981), p.39.

xliv MacNeice, Louis. Synopsis for Christopher Columbus. Included in memo from Dallas Bower to Adrian Boult (28 January 1942), R19/174.

xlv MacNeice, 'Christopher Columbus,' in Alan Heuser and Peter McDonald (eds), Selected Plays of Louis MacNeice (New York: Oxford University Press, 1992), p. 37-8. Quotations from the play hereafter cited in-text.

xlvi Patrick Deer, Culture in Camouflage: War, Empire, and Modern British Literature (Toronto: Oxford UP, 2009), p.4. 
xlvii ‘On! Sail On!,' The Listener 717 (8 October 1942), p. 456.

xlvii On Priestley's exit from the Postscripts series, see Nicholas, The Echo of War, pp. 2405, and Calder, Myth of the Blitz, pp. 196-204.

xlix On the contexts and consequences of the Beveridge report, see Angus Calder, The

People's War (London: Jonathan Cape, 1969), pp. 525-536.

${ }^{1}$ Louis MacNeice, 'London Letter [3]' (May 1941), in Alan Heuser (ed.), Selected Prose of

Louis MacNeice (New York: Oxford University Press, 1990), p. 112-113.

li Louis MacNeice, 'Christopher Columbus,' Selected Plays, p. 34.

lii Dallas Bower, 'Christopher Columbus' (14 September 1942), Folder R19/174, BBC WAC. liii BBC Listener Research Section, 'Listener Research Report 1264: Christopher Columbus' (LR/1264), 29 October 1942. BBC WAC.

liv Ibid., p. 55. 